\title{
Experimental Investigation on Safer Frother Option for Coal Flotation
}

\author{
Akira Otsuki ${ }^{*}$, Tamara Miller ${ }^{2}$ \\ ${ }^{1}$ Ecole Nationale Supérieure de Géologie, GeoRessources UMR 7359 CNRS, University of Lorraine, 2 Rue du Doyen \\ Marcel Roubault, BP 10162, 54505, Vandoeuvre-lès-Nancy, France. \\ ${ }^{2}$ WA School of Mines, Curtin University, Kalgoorlie, Australia \\ Email: akira.otsuki@univ-lorraine.fr
}

\begin{abstract}
This work aimed to investigate a safer frother for coal flotation with achieving similar or better flotation performance, compared with the most common frother methyl isobutyl carbinol $(\mathrm{MIBC})$ that caused some fire hazards in the past due to its low flash point $\left(\mathrm{F} . \mathrm{P} .=39^{\circ} \mathrm{C}\right)$. Based on the higher flash points and low risk rating according to their safety data sheet, Dow Froth 250 (F.P. $\left.=149{ }^{\circ} \mathrm{C}\right)$ and pine oil $\left(\right.$ F.P. $\left.=78{ }^{\circ} \mathrm{C}\right)$ were selected to test against MIBC. Flotation tests were carried out at various frother dosages with/without diesel as a collector. Both Dow Froth 250 and pine oil had a good potential to be a safer alternative to MIBC in terms of coal grade and recovery. Pine oil was the most promising as a stand-alone reagent without a collector potentially making for a safer work environment with less chemical storage.
\end{abstract}

Keywords: Safety, flash point, bubble size, froth image, particle size.

\section{Introduction}

Occupational health and safety $(\mathrm{OH} \& \mathrm{~S})$ must keep mining's most valuable asset, employees, safe. In Australia, for example, each state has a different set of mining regulations placed by the state government. These regulations are continuously getting stricter on items allowed in mine sites. Many metallurgical processes require the use of hazardous chemicals which can create hazards while in transport, use and disposal. As the regulations get stricter, some of these chemicals may not be allowed to be used in mine sites. This creates the need to find safer alternative chemicals or processes before employees get injured or new regulations come into place. Coal processing is one of the processes that involve hazardous reagents. The aliphatic alcohol methyl isobutyl carbinol (MIBC, $\mathrm{C}_{6} \mathrm{H}_{14} \mathrm{O}$ ) is commonly used as a frother in coal flotation and has a low flash point. It has caused many incidents including a fire at a coal processing facility in Queensland, Australia [1]. This potential MIBC issue of having a low flash point has guided this paper focus on the OH\&S to propose the use of alternative reagents in oxidised coal flotation. The aliphatic alcohol frother MIBC is generally used to improve the coal flotation kinetics. MIBC has a low flash point with vapours that are heavier than air, making it easy for an explosive atmosphere to be created.

Coal has been used as an energy source for hundreds of years, and becoming increasingly significant in recent times. In 2011, it generated $42 \%$ of the world's electricity and was recorded as one of the fastest growing energy sources [2]. There are two subsets. Thermal coal is used mainly for power generation while metallurgical coal is used in steel manufacturing. Coal can be sourced from either surface or underground mines, and in Australia the majority is surface-mined. This affects the way in which the coal is recovered and also its use as an energy source. The closer to the surface the coal recovered from, the more weathered and oxidised it becomes. The oxidised coal exhibits different properties from the underground coal with unoxidised surface. Such oxidation can make coal difficult to process. Therefore the type of coal determines the processing methods.

Thermal coal has a relatively low value, meaning that it can only be recovered by inexpensive processes. Metallurgical coal used in the manufacture of metallurgical coke is, on the other hand, worth more; so companies can use more expensive processing methods to recover. Once the coal has been mined it can be classified into four size categories: coarse $(+10 \mathrm{~mm})$, intermediate $(1-10 \mathrm{~mm})$, fine $(150$ 
$\mu \mathrm{m}-1 \mathrm{~mm})$ and ultrafine $(-150 \mu \mathrm{m})$ particles [3]. To separate the coal from gangue minerals, processes using the density differences between the coal and the gangue are used for separation of larger particles while froth flotation is used for the fine and ultrafine particles of the above categories.

Coal flotation performance is dependent on the natural hydrophobicity and size of coal particles, and the properties of reagents used. Oxidation and the coal rank also affect its flotation performance. Freshly mined coal has a higher hydrophobicity than weathered and oxidised coals either from being on the surface of the mine or stockpiled for extended periods [4]. The coal surface is naturally hydrophobic but there are a range of chemicals that are used to enhance the floatability of the coal particles and make the process more efficient. Hydrocarbon oils such as diesel oil and kerosene are often used as a collector since they are cost effective, compared with commercial collector reagents. MIBC is commonly used as a frother. There are a number of other modifiers and depressants that can be used in coal flotation to create a more efficient process and enhance the potential coal extraction. Using these reagents in flotation, however, can create unnecessary $\mathrm{OH} \& \mathrm{~S}$ hazards for coal mine sites. If OH\&S standards continue to tighten, reagents such as MIBC, which currently being warmed as a moderate risk, are not allowed to be stored on site. As a direct result of this, there is a need to develop/find alternate reagents that do not pose any safety or environmental issues.

Many coal processing facilities face the challenge of trying to float oxidised coal. Coal is oxidised by being exposed to oxygen and even a small amount is enough for oxidation to occur. According to Korte [5], the main properties of coal that are changed by oxidation are: heat value; moisture content; volatile matter content; size consistency; surface chemistry; and coking properties. The extent of these property changes varies on the coal rank. The coal structure contains natural cracks which can be enlarged when the coal particle is oxidised. It was demonstrated that low rank coals developed extensive cracks, while higher ranked coals were not physically affected by oxidation. This is due to more oxygen being exposed to the interior of the coal particles, suggesting that it is best to reduce the particle size as late as possible [4]. In other words, freshly ground coal particles avoid their oxidation and maintain a good flotation recovery. From the review of the nature of oxidised coal flotation, the following reagents were selected and compared in terms of flotation performance of the oxidised coal. They were MIBC, Dow Froth 250 and pine oil.

This study aims to find a safer coal flotation frother that does not pose any significant OH\&S hazards; but still achieve similar or better flotation performance, compared with MIBC, currently the most common frother reagent for coal flotation around the world. However, it is ranked moderate risk in the Chemical Material Safety Data Sheet (SDS) due to its low flash point [6]. The low flash point and vapour that is denser than air makes it easy for explosive atmospheres to be created. For this reason, an alternative reagent would be beneficial to the coal mining industry. Dow Froth 250 and pine oil that possess higher flash points $\left(149{ }^{\circ} \mathrm{C}[7]\right.$ and $78{ }^{\circ} \mathrm{C}[8]$, respectively) were compared with MIBC. In addition, the reagents were tested in the absence and presence of the diesel collector for dual collector and frother functions to preferentially reduce the number of chemicals to be stored on site.

This study would be beneficial for the coal industry to improve their safety and environmental standards. If the oxidised coal can be floated successfully without the use of MIBC and other reagents that can cause hazards, it can assist in a safer mining operation for employees. In addition, processing oxidised or low rank coal deposits economically viable using flotation and improving recovery can make significant profit for coal industry.

\section{$2 \quad$ Materials and Methods}

\section{$2.1 \quad$ Reagents and Coal Sample}

The following reagents were used as frothers in this study: Dow Froth 250 (polyglycol monobutyl ether, $\mathrm{CH}_{3}\left(\mathrm{C}_{3} \mathrm{H}_{6} \mathrm{O}\right)_{4} \mathrm{OH}$ ), MIBC (aliphatic alcohol, $\mathrm{C}_{6} \mathrm{H}_{14} \mathrm{O}$ ) supplied by SNF FloMin, and pine oil supplied by Sigma Chemicals. Diesel oil supplied by Caltex was used as a collector.

The experiments focused on an oxidised metallurgical coal Run of Mine sample from the Bowen Basin, Queensland Australia. First, the coal sample was spread onto a clean surface and the large coal particles not suitable for directly rod milling were crushed through a cone crusher, and then added back into the sample pile. The sample was then milled in batches using a rod mill (ESSA, 520490). Each batch was 
milled for five minutes with the mill being $30 \mathrm{vol} \%$ loaded. The milled sample was then sorted into plus and minus $500 \mu \mathrm{m}$ fractions using the Ro-tap (Tyler Industrial products, Testing sieve shaker model B). The minus $500 \mu \mathrm{m}$ fraction was then split into sub samples to approximately $250 \mathrm{~g}$ each using a riffle splitter for the flotation experiments.

\subsection{Flotation Test Procedure}

The sub sample weight was recorded and then added to the agitair flotation cell (Baker Process Technology, Agitair-model LA-500 R). The cell was then filled to the $3 \mathrm{~L}$ mark with the tap water. The agitator was started and set to $800 \mathrm{rpm}$. Diesel collector $(0,250 \mathrm{~g} / \mathrm{t})$ and a frother $(75,150,225 \mathrm{~g} / \mathrm{t})$ were added using analytical syringes and the suspension was conditioned for 3 min without air injection. The air was then turned on with a constant flow of $3 \mathrm{~L} / \mathrm{min}$. The froth was collected as a concentrate in a tray every $10 \mathrm{~s}$ using a spatula for 3 min. During each minute of flotation, a photo of the froth was taken from above the cell for further analysis. The solution $\mathrm{pH}$ was monitored by the $\mathrm{pH}$ probe (WP-80, TPS) during the conditioning and flotation. All the flotation tests were performed at the natural $\mathrm{pH}$. After $3 \mathrm{~min}$, the air injection and agitation were stopped. The concentrate in the tray was then placed under heat lamps to dry. The remaining slurry left in the flotation cell was filter pressed, placed in a tray marked as tail, and then put in an oven at $105{ }^{\circ} \mathrm{C}$ to dry. Once the products were dried, they were weighed and placed in sample bags. A split sub sample of approximately $20 \mathrm{~g}$ was taken from these samples for ash analysis to determine the flotation performance. All the flotation tests were duplicated and their average results were plotted.

\subsection{Feed and Flotation Product Analysis}

Ash analysis was completed as follows. First, each flotation concentrate and the feed were split to take two 20 g sub samples. A 20 g sample was gently mixed, and one gram of sample was carefully taken and placed into a clean and numbered crucible. The crucible with the feed/product was then placed into the cold muffle furnace (electric carbolite furnace) and it was gradually heated to $200{ }^{\circ} \mathrm{C}$. After 10 min, the furnace was then heated to $700{ }^{\circ} \mathrm{C}$ and the crucibles were left there for $3 \mathrm{~h}$. The furnace was then turned off and the crucibles were left to cool in the furnace for further $3 \mathrm{~h}$. The crucibles were then removed and placed on a steel plate to cool them down. Once their temperatures become low enough to touch, the crucibles were placed into a desiccator. When the crucibles reached room temperature they were weighed again and the ash percentage was calculated. All the measurements were duplicated and their averages were used for further calculations. By using the ash\%, the coal grade was determined and the coal recovery was calculated from the Eq.1, in order to compare the flotation performance at different conditions.

$$
\text { Coal Recovery }(\%)=\frac{(\text { Mass of coal in concentrate }) x(\text { coal grade in concentrate })}{(\text { Mass of feed }) x(\text { coal feed grade })} * 100
$$

\subsection{Particle and Froth Analysis}

Particle size distributions were analysed by sieves $(38,53,75,106,125,250,500 \mu \mathrm{m}$ openings) and the Ro-tap for the coal feed, each concentrate at $225 \mathrm{~g} / \mathrm{t}$ frother with/without $250 \mathrm{~g} / \mathrm{t}$ diesel collector to compare the effects of the reagents on the size of particle floated as a concentrate. The $D_{50}$ of the feed was $150 \mu \mathrm{m}$. All the size measurements were duplicated and their averages were plotted.

Zeta potential analysis was performed with the zeta potential analyser (Malvern, Zetasizer Nano) by the following procedure. A sample of feed coal was conditioned for 3 min with $800 \mathrm{rpm}$ agitation in the Agitair flotation cell. After $3 \mathrm{~min}$, a $10 \mathrm{~mL}$ of slurry was taken out of the cell and placed in a beaker; it was left to settle for $10 \mathrm{~min}$. A $1 \mathrm{~mL}$ of supernatant was then pipetted off and placed into the Zetasizer sample cell. This sample was then measured through the zeta potential analyser. This procedure was repeated using (a) $225 \mathrm{~g} / \mathrm{t}$ of MIBC with $250 \mathrm{~g} / \mathrm{t}$ of diesel and then (b) with $225 \mathrm{~g} / \mathrm{t}$ pine oil and 250 $\mathrm{g} / \mathrm{t}$ diesel with an additional 3 min reagent conditioning after the initial conditioning for 3 min. All the samples were prepared with tap water same as flotation experiments. All the measurements were duplicated and their average results were presented in this article. 
Analysing froth images was performed as follows. To analyse the bubble size in the cell, the images were captured by a digital camera (Panasonic Lumix) at each minute of flotation (i.e. 1, 2, 3 min), and on each image a line was drawn across the bubble surface and a circle was drawn around each bubble, assuming the bubbles are spherical. Approximately, twelve bubbles at each line were counted, and they were then sized against the ruler that was used as a scale in the images. This was repeated for the duplicated flotation tests and the average size for each minute of flotation was calculated and plotted as a function of time.

\section{$3 \quad$ Results and Discussion}

\subsection{Flotation}

Figure 1 shows the coal recovery as a function of the dosage of 3 different frothers with and without the diesel collector addition. Pine oil achieved the similar or higher recovery (65-76\%) than MIBC (70-74\%). These results are consistent with the reports from Laskowski [9] and Bhattacharya et al. [10] who also found that pine oil is a more effective frother than MIBC and polyglycol ether type frothers, such as DowFroth 250.

The coal flotation recovery without the collector also indicated the similar result (i.e. $70 \%$ vs. $76 \%$ without diesel collector) and implied that pine oil could be used as a stand-alone reagent due to its dual collector and frother abilities (Fig.1). Using pine oil can greatly improve the safety on mining sites by eliminating the needs for a potentially hazardous collector reagent, and is also a greener option due to its nature origin. It could be worth noted that Dow Froth 250 without collector achieved much higher recovery $(69 \%)$, compared with the low recovery with collector $(34 \%)$. It can be explained by the distraction of flotation performance by the diesel collector due to the competitive adsorption onto coal particles between diesel and Dow Froth 250.

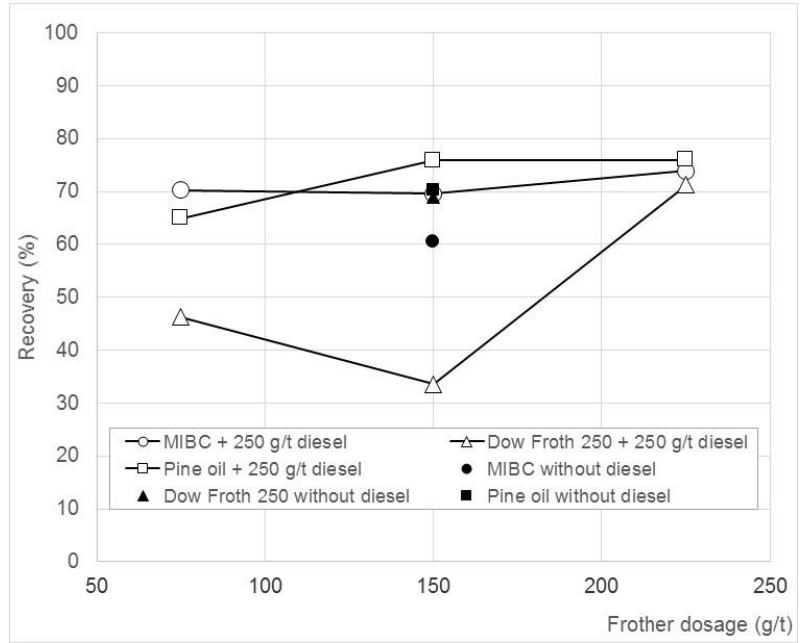

Figure 1. Coal flotation recovery with different frothers as a function of frother dosage in the absence and presence of $250 \mathrm{~g} / \mathrm{t}$ diesel collector addition.

Figure 2 shows the flotation mass recovery at different concentrations of frother. Pine oil achieved the greatest mass recovery because pine oil produces dense and small bubbles. Dow Froth 250 showed the lowest mass recovery indicating a good selectivity and allowing it produce a higher grade concentrate but poor recovery, compared with the pine oil and MIBC. Figure 2 also shows the mass recovery with no collector and showed again that pine oil has dual collecting and frother properties as the mass recovery without the diesel collector shows almost no difference from the results with the collector.

Figure 3 shows the coal grade and recovery relationship from the flotation tests with the 3 different frothers. Pine oil had the highest recovery (76\%) with the high grade (91-92\%), similar to the two other frothers (93-96\%). From this graph it can be seen that pine oil was the effective frother achieving similar results with MIBC. This satisfies the purpose of this project to find a frother with a greater flash point 
than MIBC that performs better than or equal to MIBC making the processing site safer for employees. Dow Froth 250 obtained the higher grade with lower recovery than the others. It can be used in the cleaning stage if appropriate.

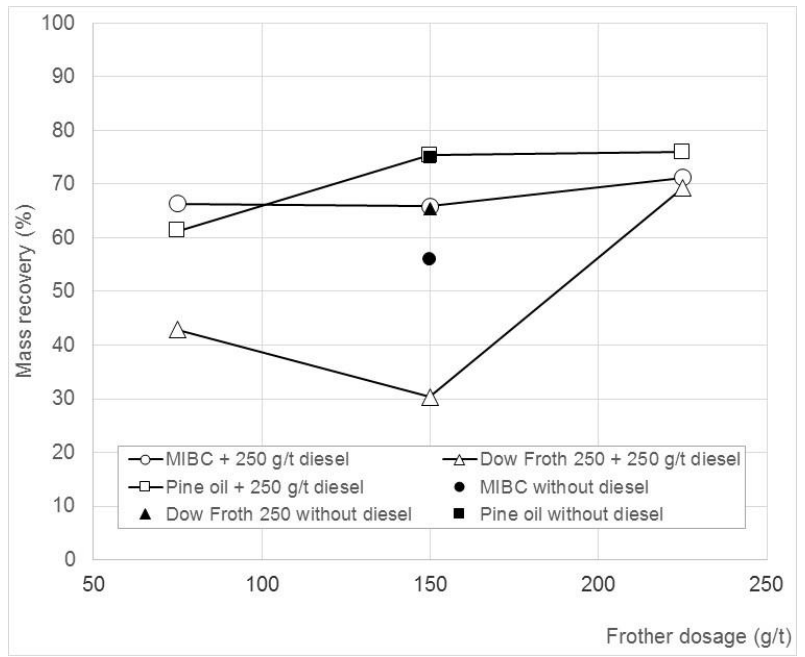

Figure 2. Flotation mass recovery with different frothers as a function of frother dosage in the absence and presence of $250 \mathrm{~g} / \mathrm{t}$ diesel collector addition.

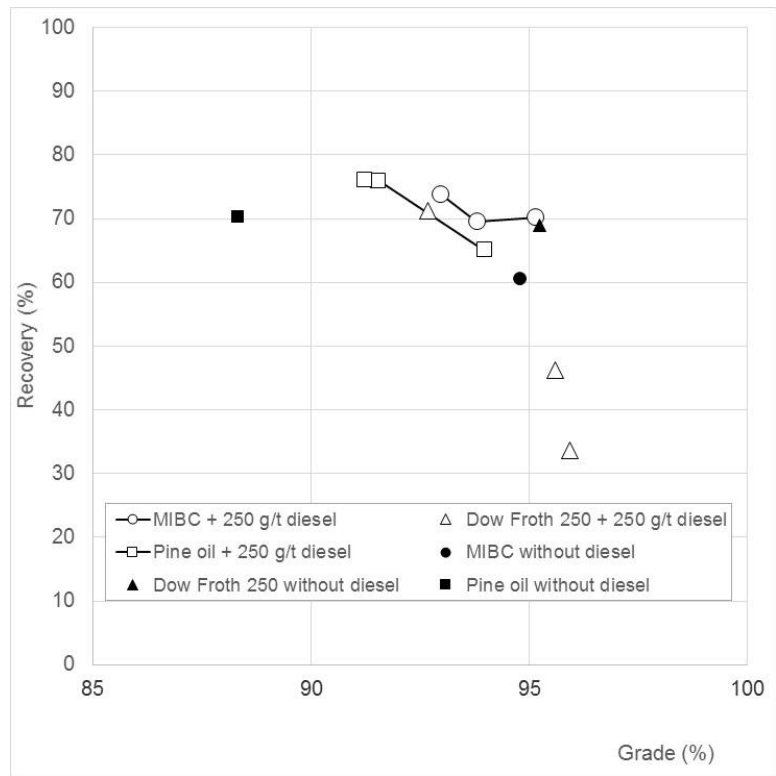

Figure 3. Grade - recovery curve of coal flotation tests with 3 different frothers in the absence or presence of 250 $\mathrm{g} / \mathrm{t}$ diesel collector.

\subsection{Particle Characterization}

Figure 4 shows the particle size distribution of the coal feed and the flotation concentrates obtained with 3 different frothers (a) MIBC, (b) DowFroth 250, and (c) pine oil. All the results show the similar trend indicating that fine particles below $105 \mu \mathrm{m}$ floated more than coarser particles floated. Especially, the mass of particles floated between 38 and $75 \mu \mathrm{m}$ was noticeably high. This trend matches with the particle size range suitable for a mechanical flotation cell [11,12]. Also, there are almost no differences 
between the particle size distribution of the concentrates in the absence and presence of the diesel collector. It suggests that all 3 frothers have the dual frother and collector properties or collector has small effect on the size distribution of the concentrate.

The $\mathrm{pH}$ was measured before the reagents were added to the test slurries. It was found that the average natural $\mathrm{pH}$ for the coal sample in 8 wt.\% solid slurry was 7.6. All the zeta potential measurements were performed under this natural $\mathrm{pH}$ since all the flotation experiments were performed at the natural $\mathrm{pH}$.

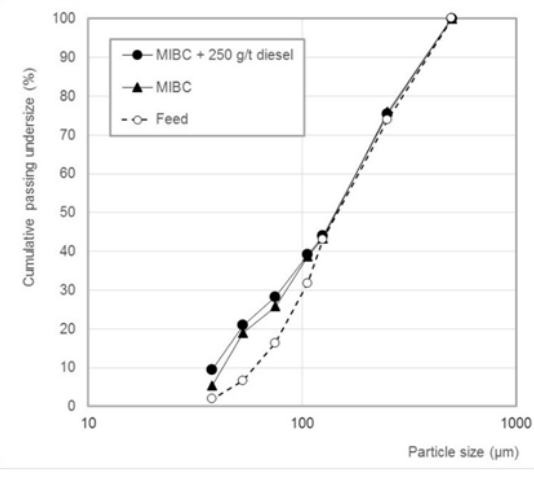

(a)

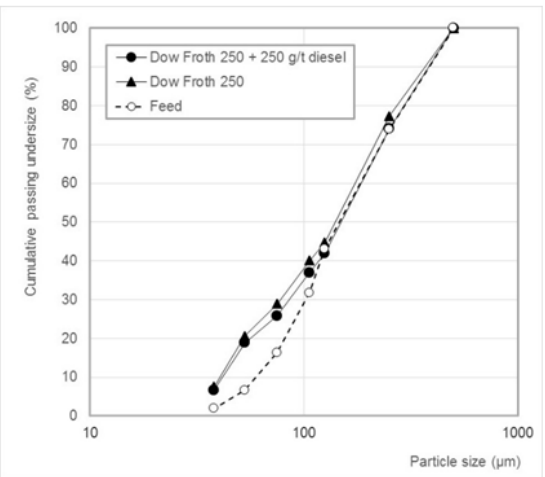

(b)

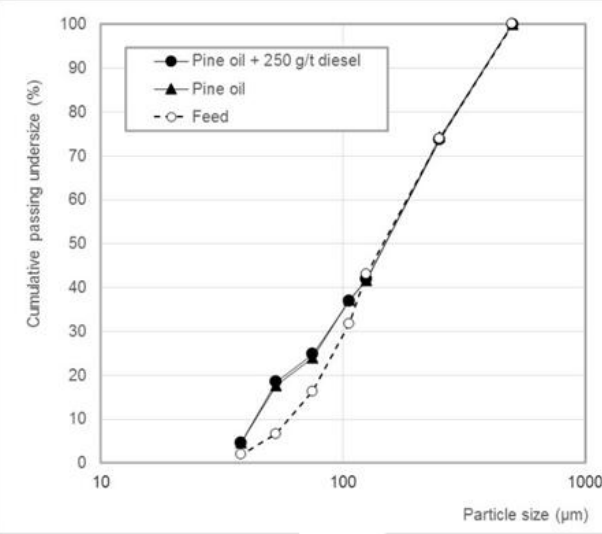

(c)

Figure 4. Particle size distribution of the feed and flotation concentrates with (a) MIBC, (b) DowFroth 250, and (c) pine oil, as a frother.

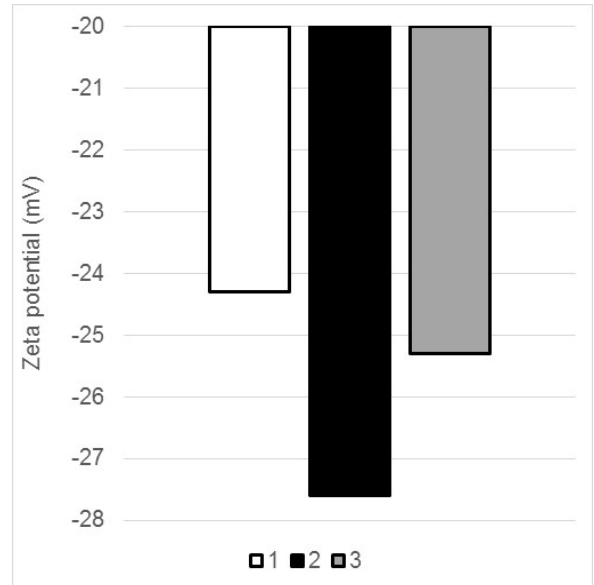

Figure 5. Zeta potential of (1) coal feed, (2) coal feed with $150 \mathrm{~g} / \mathrm{t}$ pine oil and $250 \mathrm{~g} / \mathrm{t}$ diesel, and (3) coal feed with $225 \mathrm{~g} / \mathrm{t}$ MIBC and $250 \mathrm{~g} / \mathrm{t}$ diesel, measured in the tap water. 
The zeta potential of the coal particles is related to the contact angle and hydrophobicity of the coal sample [13]; thus, it can also indicate the degree of oxidation in the coal. As the coal is oxidised, the contact angle decreases and the zeta potential charges more negatively. By comparing the zeta potential of the feed and the feed with the flotation reagents, it is possible to predict the particle behaviour during the flotation.

Figure 5 shows the zeta potential of three different slurries at $\mathrm{pH}$ 7.6. They are (1) coal feed, (2) feed with $150 \mathrm{~g} / \mathrm{t}$ pine oil and $250 \mathrm{~g} / \mathrm{t}$ diesel, and (3) feed with $225 \mathrm{~g} / \mathrm{t}$ of MIBC and $250 \mathrm{~g} / \mathrm{t}$ diesel. Conditions (2) and (3) were selected for the highest recoveries obtained among other frother dosages of the same frother (i.e pine oil or MIBC). These samples modelled flotation conditions did not show a large difference between the three conditions. It explains the small variation in results from the different frothers.

The previous research of Wen and Sun [13] showed that the increase in zeta potential negatively decreased the contact angle reducing the hydrophobicity of the coal and making it more difficult to separate from gangue minerals due to less differences in physico-chemical properties between coal and gangues. The results in this study show that the coal sample was not heavily oxidised when comparing with the zeta potentials reported by Korte [4]. In the use of his results, the zeta potentials of $-25 \mathrm{mV}$ and $-30 \mathrm{mV}$, around which we observed in this study, represent the contact angles of $75^{\circ}$ and $70^{\circ}$, respectively. The lowest contact angle he observed, on the other hand, was $55^{\circ}$ at the zeta potential of $48 \mathrm{mV}$, which is two times bigger than the measured value of our feed.

It can be seen that at a zeta potential of $-25 \mathrm{mV}$ there has not been a great change in the contact angle as opposed to the further oxidised coal which is more hydrophilic with the smaller contact angle. The works of Laskowski [9], Bhattacharya [10] and Wen and Sun [13] show that MIBC is an ineffective frother for oxidised coal. The zeta potential results show why the MIBC was able to float the coal as effectively as the pine oil frother investigated in this study.

\subsection{Froth Image Analysis}

Using a digital camera mounted on a retort stand, photos of the froth were taken at approximately one minute intervals. These images were then analysed for the average bubble size and the texture of the produced froth to investigate if there was a relationship between the flotation recovery and visual properties of the froth. If there was a relationship and appropriate camera and programming technology was applied, it could be a way for plant operators to get direct feedback on how the flotation circuit is operating without waiting for the assay results of samples from laboratories.

\section{Froth texture}

Analysing the texture of the froth in the flotation cell can be an indicator of the flotation performance. The method of analysing the froth texture can be subjective; thus a number of key points on the observation needed to be established for this method to properly work. The ideal froth appearance also varies from plant to plant as well as with ore type, reagents and cell geometry used [14, 15]. Three main froth categories were described by Wright [14] and Holtham and Nguyen [15]:

- Ideal froth - keeps a balance between too runny and too viscous froth. It has closely packed bubbles with clear areas on top of some bubbles.

- $\quad$ Runny froth - is watery and excessively mobile with low mineralization. The bubble size is too small and the bubbles are unstable.

- Viscous froth - has low mobility and high mineralization. The bubbles are large and elliptical in shape and the froth is too stable.

Other notable features of froth texture are clear windows appearing on top of the bubble surface and local bubble collapse. The clear windows seen in Fig. 6 formed on top of the bubbles indicate that the froth was being under loaded by the mineral particles. Local bubble collapse occurs when the froth is overloaded with the mineral particles, it can be seen when black holes appear on the froth surface as in Fig. 7. Local bubble collapse in a plant scale is a precursor to global bubble collapse if the plant operators cannot find the cause. The causes of these two froth events are varied from changes in mineral type, surface properties or inappropriate reagent dosage [16]. 


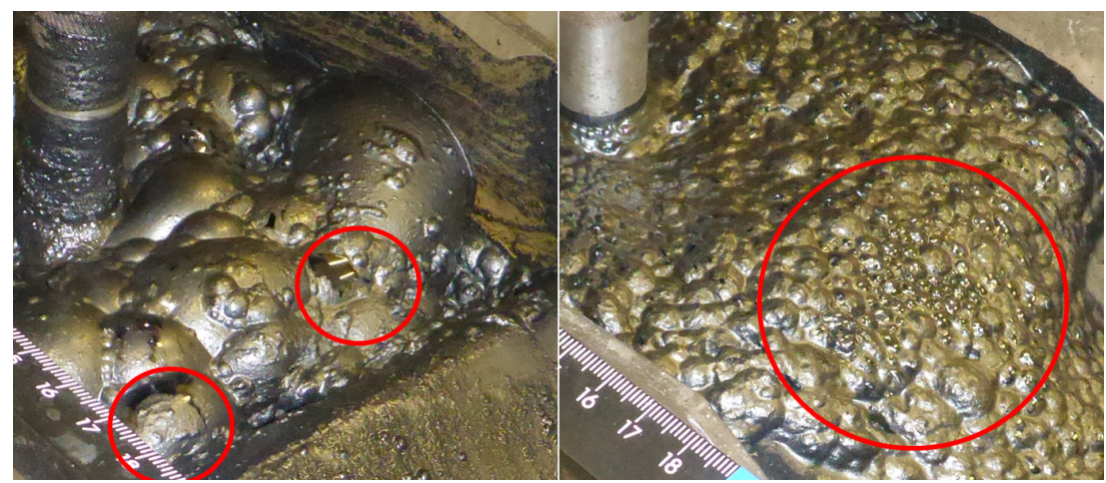

Figure 6. Example of bubble windows from the froth images during coal flotation.

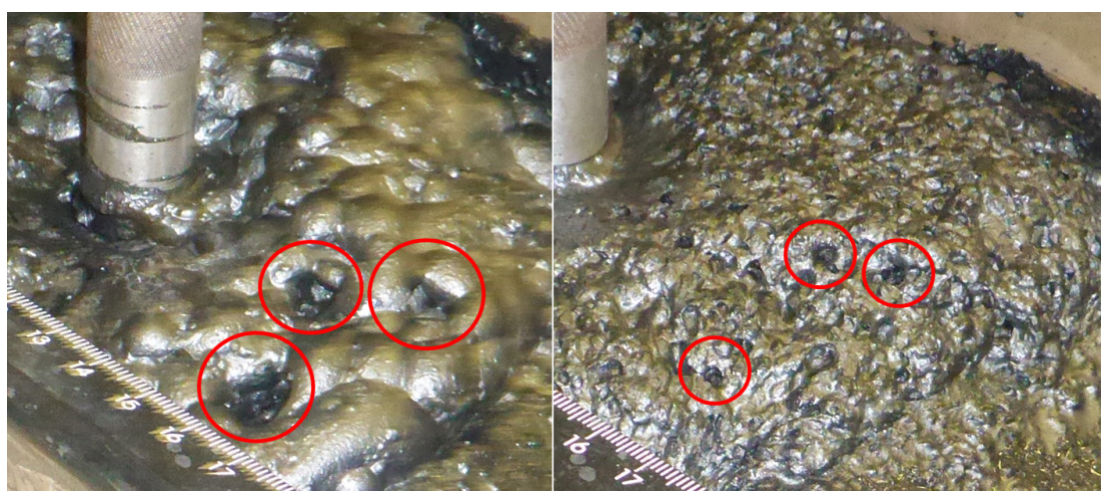

Figure 7. Example of local bubble collapses from the froth images during coal flotation.

From the froth images, it was found that Dow Froth 250 produced the most ideal froth (Fig. 8-b) among all the test conditions. This is due to its ability to produce tough and compact froth that lasts longer in a flotation cell compared to the other frothers. The MIBC froth produced the clearest windows (e.g. Fig. 6, 8-a-2) under all the conditions, indicating under loading of the froth. This makes MIBC potentially not suitable for this coal sample if the surface properties of the coal are not compatible with the frothing properties of MIBC. When using pine oil as the frother in the test work there were a number of cases of local bubble collapse (e.g. Fig. 7, 8-c-2). This is due to overloading the froth as pine oil creates small and tight bubbles that do not allow effective drainage of water and gangue material. This was reflected in the coal recovery and grade with pine oil having a higher recovery but slightly lower grade than the other frothers. However, the overloading effect on the flotation performance was seen to be limited as shown in Fig. 3. 

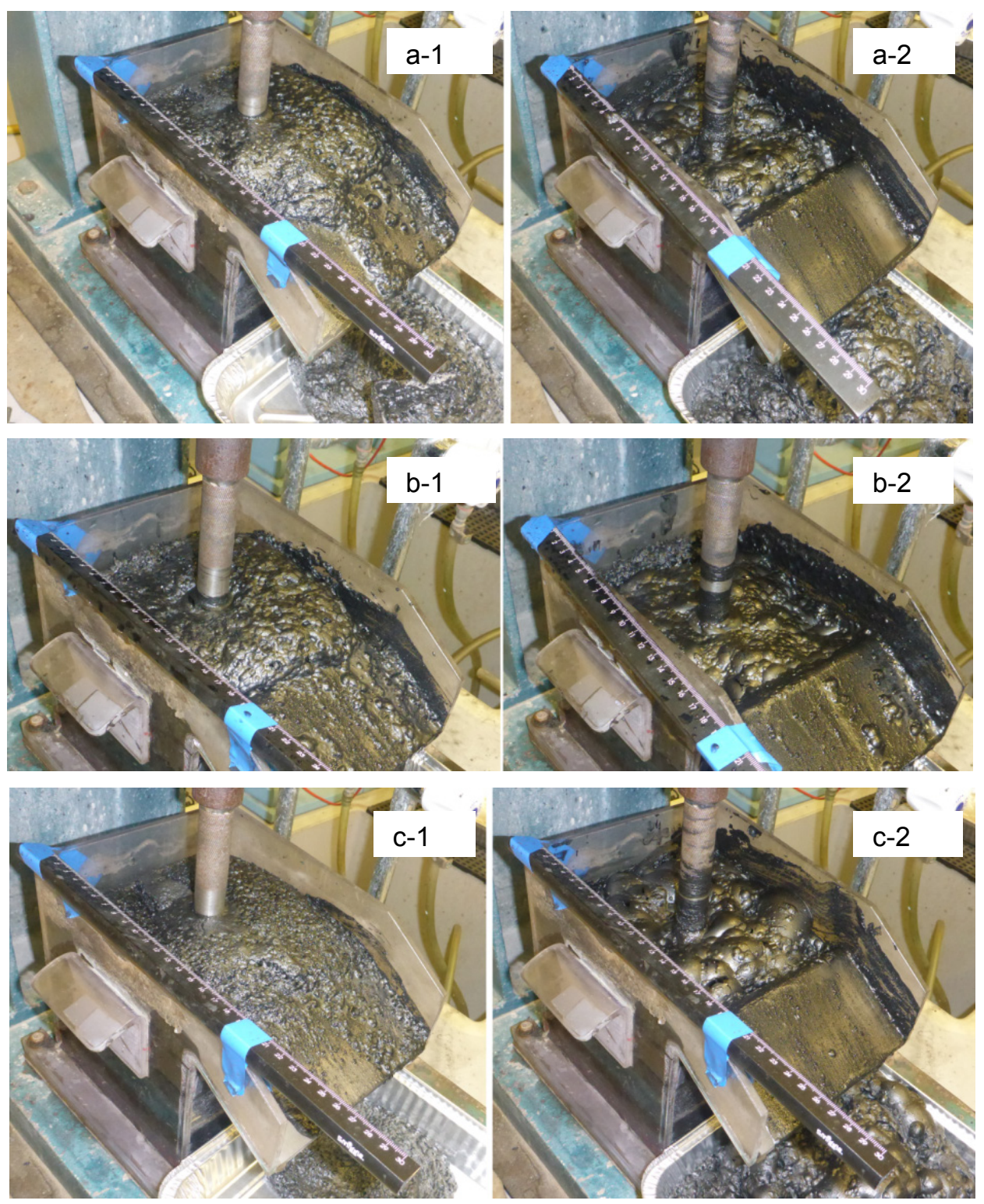

Figure 8. Froth images of coal flotation with (a) MIBC (after $1 \mathrm{~min}$ (a-1) and 3 min (a-2) of flotation), (b) DowFroth250 (after $1 \mathrm{~min}$ (b-1) and $3 \mathrm{~min}$ (b-2) of flotation), and (c) pine oil (after $1 \mathrm{~min}$ (c-1) and 3 min (c-2) of flotation).

The texture of the froth also changed in each minute of flotation. The clear windows formed in the bubbles are more likely to occur in the three min of flotation while the bubble collapses more likely in one min. This is due to the smaller concentrations of the frother in the cell with time. As flotation continues, some of the frother float with the concentrate lowering its concentration in the flotation cell affecting the surface properties of the bubbles and mineral particles. As shown in Figs. 8, the comparison between 1 min and 3 min of flotation with different frothers showed the similar trend. After $1 \mathrm{~min}$ bubbles were fine and densely packed while after 3 min bubbles became large and their size varied due to lower concentration of the frother available in the flotation cell to keep the good froth.

\section{Bubble size}

Figure 9 shows the typical results of bubble size measurement with $150 \mathrm{~g} / \mathrm{t}$ of 3 different frothers with/without diesel collector as a function of time. From the measurement, several conclusions can be drawn. As pointed out also in the above section, the bubble size increased with increasing the flotation 
time due to the less frother concentration in the flotation cell with time. Changes in bubble size was small with MIBC and Dow Froth 250 (i.e. less than a factor of 2) during 3 min of flotation while the size significantly increased with time by pine oil (i.e. higher than a factor of 3 to 4 ) indicating the bubble instability. The stability with MIBC and Dow Froth 250 indicates that there was a constant rate of coal being floated during the three min test, allowing the frother to be more easily monitored and then adjusted if needed in a plant setting. Without collector, bubble size generally depressed with Dow Froth 250 and pine oil while the bubble size with MIBC slightly increased without collector. Their depression can be explained by less competitive adsorption of frother molecules onto bubbles without collector.

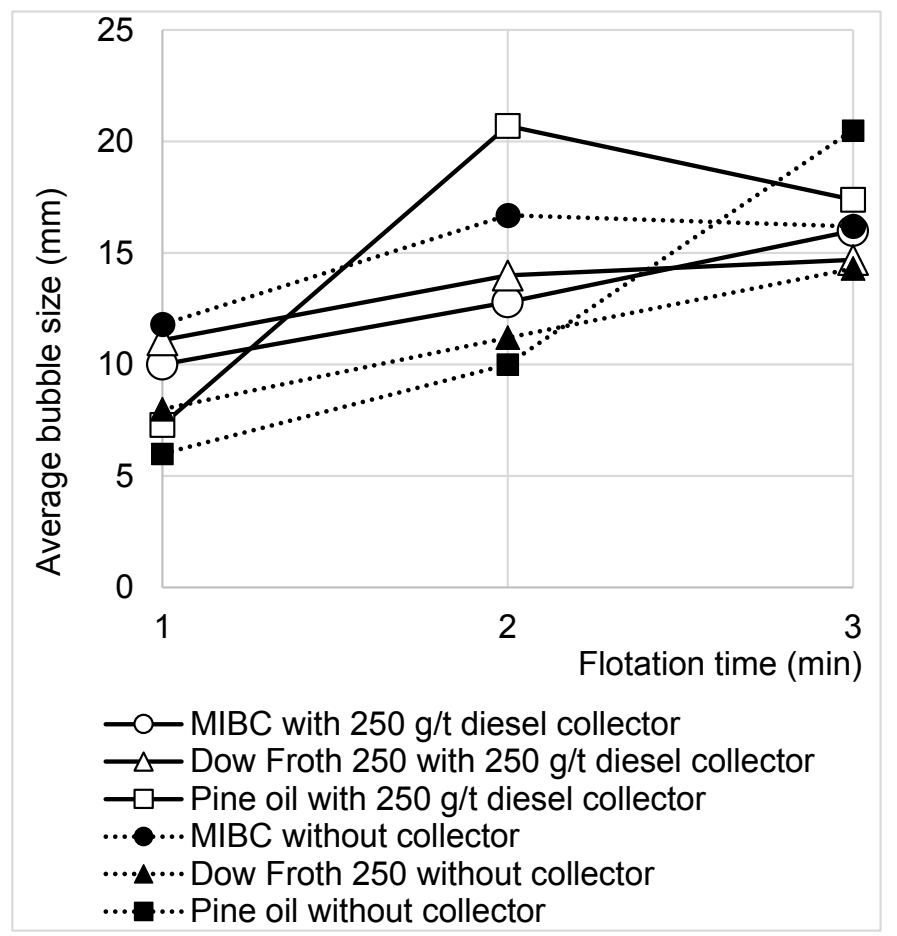

Figure 9. Average bubble size during coal flotation with $150 \mathrm{~g} / \mathrm{t}$ of 3 different frothers in the presence and absence of $250 \mathrm{~g} / \mathrm{t}$ diesel collector as a function of flotation time.

The sizes of bubbles produced during flotation are one of the factors that can be visually monitored. Producing a consistent bubble size in flotation cells can ensure a consistent concentrate. Figure 10 shows the average bubble size at each min of flotation with different frother types ((a) MIBC, (b) DowFroth250, (c) pine oil) and concentrations $(75,150,225 \mathrm{~g} / \mathrm{t}$ ) in the presence of $250 \mathrm{~g} / \mathrm{t}$ diesel collector. Bubbles produced with pine oil started off small and then the size increased rapidly. This indicates that the frother behaved differently during each minute of flotation. It had the greatest effect in the first min of flotation producing small dense bubbles that are highly loaded. With time, the bubble size quadruples and at the end of the flotation test the bubbles are too stable and are being under loaded with coal particles due to the windows forming on the bubbles.

For all the 3 frothers, when their concentrations were $225 \mathrm{~g} / \mathrm{t}$ of frother with $250 \mathrm{~g} / \mathrm{t}$ diesel collector, the average bubble size across the $3 \mathrm{~min}$ was the smallest. This is due to the frother dosage closer to its critical coalescence concentration (CCC) where the bubble size is no longer controlled by coalescence but by the geometry of the cell, air flow rate, the impellor shape, and agitation speed. As shown in Fig. 10 (c), the bubble size with pine oil starts off small and then expands in the 2 min before decreasing the average size once again. This suggests that they have a lower CCC than the other frothers which did not exhibit such a trend until the concentration of frother reached $225 \mathrm{~g} / \mathrm{t}$ (Figs. 10 (b) and (c)).

This test work showed that monitoring bubble size is a way that processing plant operators can get visual feedback on the performance of their flotation cells once the optimal bubble size is identified for the specific ore or plant. 

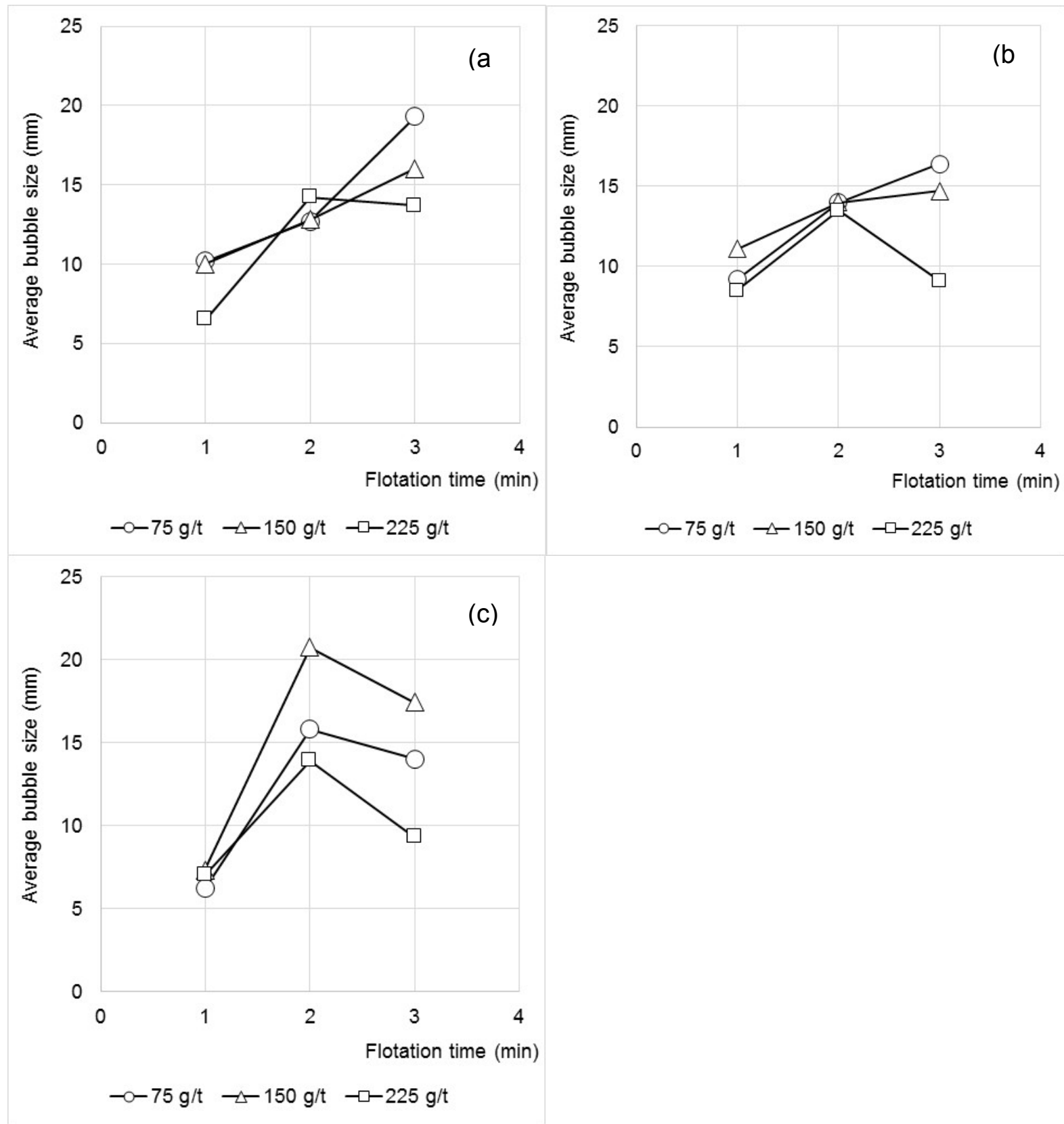

Figure 10. Average bubble size during coal flotation with 3 different concentrations $(75,150,225 \mathrm{~g} / \mathrm{t}$ ) of (a) MIBC, (b) DowFroth250, and (c) pine oil, as a frother with $250 \mathrm{~g} / \mathrm{t}$ diesel collector, as a function of flotation time.

\section{Conclusions}

The purpose of this study was to investigate coal frothers that are safer and greener than MIBC but can also provide equal or better flotation performance. From the reagent safety analysis and previous work it was found that pine oil and Dow Froth 250 have a higher flash point and thus are selected as safer potential options in this study. They were tested along with MIBC at various concentrations with and without a collector. Also, as part of this project, the visible features of the froth were analysed to investigate if there were any correlations with the coal grade and recovery. A visual indication of the 
flotation performance would be much less time consuming and cost effective in a processing plant than collecting samples and sending them to the laboratory for analysis.

After completing the experimental program for the safer flotation of oxidised coal, it was concluded that:

- Pine oil $\left(\right.$ F.P. $\left.=78{ }^{\circ} \mathrm{C}\right)$ achieved the high coal grade $(91-92 \%)$ and recovery $(76 \%)$, similar to the results with $\mathrm{MIBC}\left(\mathrm{F} . \mathrm{P} .=41{ }^{\circ} \mathrm{C}\right)$. Pine oil is a safer alternative over MIBC.

- Pine oil has the dual properties as frother and collector. The flotation performance in the presence and absence of the diesel collector was almost identical. Pine oil has the potential to be used as a stand-alone reagent for coal flotation. It can remove a potentially hazardous collector (e.g. diesel) from the site and creating a safer environment.

- Dow Froth 250 was the most selective frother among 3 frothers, indicated by the highest grade but low mass recovery. DowFroth 250 has the highest flash point making it safer than MIBC. It can be used in a cleaning stage over MIBC where appropriate.

In regards to the bubble size and texture analysis it was revealed that:

- The analysis can be practically useful in plant operations to identify the potential issues during flotation. They are strongly correlated with two visually identifiable froth events indicating the quality of flotation. Clear windows forming at the top of bubbles and localised bubble collapse which can identify the bubbles as being under loaded or over loaded, respectively.

- DowFroth 250 was found to produce the most constant bubble size during the three minutes of flotation in comparison with the other two frothers. From this information, it can be concluded that DowFroth 250 would be the easiest frother to manage in a plant setting as the operators can get visual feedback if there are any changes occurring in the flotation cells after the optimal bubble size is identified.

\section{Acknowledgement}

The authors wish to acknowledge their gratitude to Mr. Bembrick who provided samples and chemicals.

\section{References}

1. Garland, P. 2003. Fire at an MIBC Pump. Safety Alert No.112. Queensland: Queensland Government.

2. WORLD COAL ASSOCIATION. 2012. Coal Statistics [Online].

Available: http://www.worldcoal.org/resources/coal-statistics/ [Accessed 4th April 2013].

3. Aaron, N., Luttrell, G.H. 2015. A review of state-of-the- art processing operations in coal preparation. Int. J. Min. Sci. Tech., 25, 511-521.

4. Polat, M., Polat, H. \& Chander, S. 2003. Physical and chemical interactions in coal flotation. International Journal of Mineral Processing, 72, 199-213.

5. Korte, G. J. D. 2001. Beneficiation of Weathered Coal. Republic of South Africa: CoalTech 2020.

6. DOW CHEMICAL (AUSTRALIA) 2013. Methyl Isobutyl Carbinol. Safety Data Sheet.

7. DOW CHEMICAL (AUSTRALIA) 2011. Dowfroth 250. Safety Data Sheet.

8. Spectrum 2008. Pine oil. Safety Data Sheet.

9. Laskowski, J. 2001. Coal Flotation and Fine Coal Utilization. Burlington: Elsevier Science.

10. Bhattacharya S. Dey S., and Ahmad, M.Z. (2004) Frother Dependency in Coal Flotation. International Seminar: Mineral Processing Technology, Bhubaneshwar, 566-575.

11. Jameson, G.J. Minerals Engineering 23 (2010) 835-841.

12. Michael J. Mankosa1, Jaisen N. Kohmuench1, Gerald H. Luttrell, John A. Herbst and Aaron Noble, IMPC2016.

13. Wen, W. W. \& Sun, S. C. 1981. An Electrokinetic Study on the Oil Flotation of Oxidized Coal. Separation Science and Technology, 16, 1491-1521.

14. Wright, B. A. 1999. The Development of a Vision-Based Flotation Froth Analysis System. Master of Science in Engineering, University of Cape Town.

15. Holtham, P. N. \& Nguyen, K. K. 2002. On-line analysis of froth surface in coal and mineral flotation using JKFrothCam. International Journal of Mineral Processing, 64, 163-180.

16. Liu, J. J., Macgregor, J. F., Duchesne, C. \& Bartolacci, G. 2005. Flotation froth monitoring using multiresolutional multivariate image analysis. Minerals Engineering, 18, 65-76. 